\title{
WRMSD Related to Manual Material Handling of Indian Railway Porters
}

\author{
Ekta Melkani*, Ekta Kapri and Manju Mehta \\ Department of Family Resource Management, CCSHAU, Hisar Haryana, India \\ *Corresponding author
}

\section{Keywords}

Indian railway porters, WRMSDs,

Limit (RWL),

Lifting Index (LI) and manual material handling, etc.

Article Info

Accepted:

18 March 2020

Available Online:

10 April 2020

\section{A B S T R A C T}

Indian railway employs around 20,000 of Railway porters for the heavy load of work causing discomfort to their body in most elephantine way. Twelve porters were randomly selected from purposively selected areas, Old Delhi and Jalandhar (Punjab) Railway Stations (six from each) for the study during the busiest time of Guru Nanak Jayanti. Nordic Musculoskeletal Questionnaire was used to log the personal profile and musculo-skeletal discomfort of the respondents. The NIOSH Lifting Equation tool was used to assess the manual material handling risks associated through values of Recommended Weight Limit (RWL) and Lifting Index (LI). According to devised task categories, neck and lower back (100\% each), ankles (91.67\%), wrists/hands and upper back (83.33\% each) and shoulder $(75.00 \%)$ were the majorly affected body parts within a year. Lifting and carrying heavy loads for the porters and storehouse activities were found more hazardous than cart dragging in light of high LI values occupied. Government regulations and protective equipments are strictly recommended for the health care of porters.

\section{Introduction}

"The Indian Railways will become the growth engine of the nation's vikas yatra", said Hon. Prime Minister Shri Narendra Modi. This journey of Indian railway buoys up around 20,000 of Railway porters (coolies) to earn their livelihoods and raise their children for a better life. But sometimes, in fact many a times, the heaviness of work and discomfort caused to one's body is underestimated for a few bucks. In the long run, even if they succeed in earning 400 Rupees a day, a sound sleep will take its time because of the strain effects over body. At the origin or depart of our rail journeys, we often come across a familiar figure, most of the time in a red turn out having his head and shoulders resting heavy suitcase and baggage, endlessly running from one platform to another.

The color of their dress might be reflecting vibrance and radiance but life certainly is not so colorful for them. Their hardships and nettles have no endings from dusk till dawns. The discomfort is both physical as well as 
psychological. The physical strains are the effects of carrying load while the fewer earnings are the causes of mental irritations.

The following research proposes the major areas exposed to discomforts caused by porting occupation and the comparison between the recommended and the existing lifting index of load among the porters. Even in the old age, porters are forced to work for their livelihood which is the main reason for their recitation for retirement plans demands from the Government. The health issues and body aches multiply in their old age which need frequent medical attentions. This created another reason for the financial security of their children too, so that indirectly they may get medical advantages. A brief picture about their work related musculo-skeletal disorders (WRMSDs) is demonstrated in the research giving arousal to a number of future possibilities.

\section{Materials and Methods}

For the revelation of WRMSD among the Indian porters, 12 porters were randomly selected from the Old Delhi and Jalandhar (Punjab) Railway Stations (six from each). The areas were selected purposively for the study as they were the busiest stations during the time of observation (Guru Parv) and Porters were identified with sufficient work.

Nordic Musculoskeletal Questionnaire was used to $\log$ the personal profile and musculoskeletal discomfort of the respondents. The discomforts observed were tabulated categorically for interpretation. The aim was to develop comparison of discomfort among the lower back, neck, shoulder and general complaints.

The NIOSH Lifting Equation tool was used to assess the manual load handling risks associated with lifting and lowering tasks performed by the porters. A Lifting Index (LI) was also calculated to provide a relative estimate of physical stress level and MSD risk associated with the manual porting tasks evaluated. The Recommended Weight Limit (RWL), defining the maximum acceptable weight (load) allowed to lift over by the healthy workers during the course of an 8 hour shift without increasing the risk of musculoskeletal disorders (MSD) to the lower back was provided. Luggage lifting and carrying for passengers, cart dragging and storehouse duties for loading and unloading luggage and goods were the categories devised for comparison of task performed and related discomforts analysis. The results were then compared with the standard safe load carrying practices and guidelines.

Respondents were observed for minimum of 15 minutes for the work they did repetitively and were taken for longer time if their work demanded more time for completion. As the NIOSH Lifting Index deals with the lifting of loads only, activities like cart dragging were observed the apparent weight they lift and the bent posture in which they drag it. Weights of the loads were either asked from the passengers who had earlier weighed it for weigh limit guidelines or for a few respondents, it was weighed with the selfcarried weighing balance of $100 \mathrm{~kg}$ limits.

\section{Results and Discussion}

The personal and work profile details of the railway porters were collected so that their health and other work dividends can be correlated to the severity of their discomfort level later. All the respondents selected for the study were males as majority of the porters consist of male workers which might be because of more physical strength among men. Half of the respondents $(50 \%)$ were found to be aged between 35 to 50 years, followed by one fourth of the respondents among age group of 20 to 35 years and 
between 50 to 60 years. Similarly most of the workers were found to be in the occupation for 15 to 30 years $(41.67 \%)$ followed by one third of the respondents $(33.33 \%)$ working for even more than 30 years. Only 16.67 per cent of porters were working since 5 to 15 years while even less $(08.33 \%)$ were working for less than five years. All the porters had their basic occupation as of lifting and carrying load for the travellers which was followed by three-fourth of the workers who were using carts to carry loads either for storage areas or for the travelling customers. Only one third of the porters $(33.33 \%)$ were also working as storage labourers for loading and unloading activities along with porting works.

Work-related musculo skeletal disorders felt by porters were observed among their various body parts based over the discomfort felt in the last12 months, affected normal works due to discomforts and trouble during last 7 days. Neck and lower back (100.0\%) followed by ankles $(91.67 \%)$ were found to be most affected body parts among the porters having discomfort for past one year. Upper back
$(83.33 \%)$, right shoulder $(75.00 \%)$ and knees $(66.67 \%)$ were the other major areas affected. Discomfort in many body parts prevented porters in the past from doing normal work because of the major trouble by lower back and ankles (58.33\% each) and right hands/wrists $(50.00 \%)$. Neck $(75.00 \%)$ and lower back $(58.33 \%)$ were the main body parts which were troubled at any time during last 7 days by and kind of discomfort caused by the porting activities.

The mean recommended weight limit was found for various lifting activities performed by the porters. The activities and average weight carried by porters were classified under the domains where all the respondents were lifting and carrying loads for passengers (36 kg), nine porters dragged loads over the carts also (29.4 kg) (using guidelines that manual carts should not load more than 200 $\mathrm{kg}$ and the maximum weight a person should lift is $25 \mathrm{~kg}$ ) and only four among them were also involved in storage activities in godowns $(32 \mathrm{~kg})$. The relative magnitude of physical stress for lifting loads was estimated through Lifting Indices (LI) (Table 1-3).

Table.1 Personal Details $(\mathrm{n}=12)$

\begin{tabular}{|c|c|c|c|}
\hline S. No. & \multicolumn{2}{|c|}{ Category } & Frequency $(\%)$ \\
\hline \multirow[t]{2}{*}{1} & Gender & Male & $12(100 \%)$ \\
\hline & & Female & - \\
\hline \multirow[t]{3}{*}{2} & Age & $20-35$ yrs & $3(25.00 \%)$ \\
\hline & & $35-50$ yrs & $6(50.00 \%)$ \\
\hline & & $50-65$ yrs & $3(25.00 \%)$ \\
\hline \multirow[t]{4}{*}{3} & Work Duration & $<5 \mathrm{yrs}$ & $1(08.33 \%)$ \\
\hline & & $5-15$ yrs & $2(16.67 \%)$ \\
\hline & & $15-30 \mathrm{yrs}$ & $5(41.67 \%)$ \\
\hline & & $>30 \mathrm{yrs}$ & $4(33.33 \%)$ \\
\hline \multirow[t]{3}{*}{4} & Work Types & Lifting and carrying load & $12(100 \%)$ \\
\hline & & Storehouse functions & $4(33.33 \%)$ \\
\hline & & Cart dragging & $9(75.00 \%)$ \\
\hline
\end{tabular}


Table.2 Musculo-skeletal with Locomotive Organs $(n=12)$

\begin{tabular}{|c|c|c|c|c|c|}
\hline S. No. & \multicolumn{2}{|c|}{ Body Parts } & $\begin{array}{l}\text { Ache/ pain/ } \\
\text { discomfort during } \\
\text { the last12 months }\end{array}$ & $\begin{array}{c}\text { Discomfort } \\
\text { prevented from } \\
\text { doing normal work } \\
\text { because of the } \\
\text { trouble }\end{array}$ & $\begin{array}{c}\text { Trouble at any } \\
\text { time during last } 7 \\
\text { days }\end{array}$ \\
\hline 1. & \multicolumn{2}{|l|}{ Neck } & $12(100.00 \%)$ & $4(33.33 \%)$ & $9(75.00 \%)$ \\
\hline \multirow[t]{3}{*}{2.} & Shoulder & Right & $9(75.00 \%)$ & $3(25.00 \%)$ & $2(16.67 \%)$ \\
\hline & & Left & $4(33.33 \%)$ & - & - \\
\hline & & Both & $2(16.67 \%)$ & $1(08.33 \%)$ & - \\
\hline \multirow[t]{3}{*}{3.} & Elbow & Right & $6(50.00 \%)$ & $2(16.67 \%)$ & $2(16.67 \%)$ \\
\hline & & Left & $2(16.67 \%)$ & $1(08.33 \%)$ & - \\
\hline & & Both & $3(25.00 \%)$ & - & $1(08.33 \%)$ \\
\hline \multirow[t]{3}{*}{4.} & Wrists/Hands & Right & $\mathbf{1 0}(83.33 \%)$ & $6(50.00 \%)$ & $3(25.00 \%)$ \\
\hline & & Left & $6(50.00 \%)$ & $1(08.33 \%)$ & - \\
\hline & & Both & $2(16.67 \%)$ & - & $1(08.33 \%)$ \\
\hline 5. & Upper back & & $10(83.33 \%)$ & $4(33.33 \%)$ & $4(33.33 \%)$ \\
\hline 6. & Lower back & & $12(100.00 \%)$ & $\mathbf{1 0}(83.33 \%)$ & $7(58.33 \%)$ \\
\hline 7. & Hips/Thighs & & $5(41.67 \%)$ & $2(16.67 \%)$ & $2(16.67 \%)$ \\
\hline 8. & Knees & & $8(66.67 \%)$ & $4(33.33 \%)$ & $3(25.00 \%)$ \\
\hline 9. & Ankles & & $11(91.67 \%)$ & $7(58.33 \%)$ & $3(25.00 \%)$ \\
\hline
\end{tabular}

Table.3 Recommended Weight Limit (RWL) and Lifting Index (LI) $(n=12)$

\begin{tabular}{|l|l|c|c|}
\hline S. No. & Functions & RWL & Lifting Index \\
\hline 1. & Lifting and carrying load (12) & 12.92 & $\mathbf{2 . 7 9}$ \\
\hline 2. & Storehouse functions (3) & 12.89 & $\mathbf{2 . 4 8}$ \\
\hline 3. & Cart dragging (9) & 16.60 & $\mathbf{1 . 7 7}$ \\
\hline
\end{tabular}

The greater LI means smaller fraction of workers capable of safely sustaining the level of activity. In the conducted study LI was found maximum among lifting and porting load (2.79) followed by storehouse activities (2.48) i.e. significant level of physical stress and health concerns are related in both activities. Whereas cart dragging was found to be a little safe but can begin with physically stressful. None of the activity attained LI score less than 1 declaring the porting occupation safe and healthy.

The occupation of porters is basically a male dominant portion of the society mainly due the physical strength required for heavy load carrying tasks. Similarly the results have been obtained for the case here. Respondents were taken purposively from the places but naturally they were selected randomly from the stations and were all males. Most of them belonged to middle age having work experience of two to three decades.

Majority of the respondents worked only as porters for passengers and most among them used carts for porting luggage or other materials to storage house. Neck and lower back (100 \% each), ankles (91.67 \%), wrists/hands and upper back (83.33\% each) 
and shoulder $(75.00 \%)$ were the majorly affected body parts reported among the porters which they concluded as troublemakers for over a year. Lower back $(83.33 \%)$, ankles $(58.33 \%)$ and hands $(50.00$ $\%)$ were the other body parts which due to injury, pain or discomfort caused the porters to be concerned while doing routine tasks. Neck $(75.00 \%)$ and lower back (58.33 \%) were the most affected body parts which faced musculo-skeletal disorders among majority of the respondents over the duration of a week. Overall, work related musculoskeletal disorders (WRMSDs) were of high enumeration among the porters of railways from Jalandhar and Delhi.

Lifting tasks with a Lifting Index more than 1.0 create an increased risk for lifting-related musculo-skeletal pain. If the magnitude of the LI increases 1.0, the level of the risk for the worker performing the job would be increased; and for 2.0 and > 3.0, a greater percentage of the workforce is at risk for developing low back pain and even an increased risk of a work-related injury for the later one. Here, cart dragging full of heavy loads occupied lifting index of 1.77 which can increase the musculo-skeletal pain (especially lower back) by the porter. Lifting and carrying heavy loads for the porters and storehouse activities are even more dangerous having LI 2.79 by the former activity, which is close to 3.0. The later had the LI of 2.49 with heavy risk of developing lifting-related low back injuries. The aim should be to design all lifting jobs achieving a LI of 1.0 or less.

\section{Recommendations}

Standard weight which is allowed to be lifted overhead should be $1 / 3^{\text {rd }}$ of body weight of a person which is far less than what is actually carried by the poor Indian porters. The weights should be legally reduced per head porters for their health as health is the real wealth especially for the ones who use their physical strength for their livelihood earning.

The minimum charges should be fixed according to the weight carried in the favor of the porters so that they carry weight only which is easy for them to carry earning maximum benefits out of it.

Easy to handle and maintain carts can be provided by the governments to make the work easier for the porters.

Regular and free health check-ups and health maintenance provisions should be carried out for the health of an important group of our society which has existed for years and shall sustain widely for futures as Indian Railway network is the largest among the world.

Ergonomic development with some tools, equipments or devices can be directed or influenced in the favor of porters to make their work easier and strain free.

Lower back, head and shoulder supports in the forms of protective equipments should be designed in order of creating healthy and comfortable porting occupation. Gloves can be provided or developed for easy gripping of luggage and reducing hand pains and injuries. The increased comfort level should definitely help the porters to reduce their Lifting Index below 1.0 and at the same time reducing the humongous rates of WRMSDs for their occupation.

\section{Practitioner summary}

Porters were identified; Nordic Musculoskeletal Questionnaire was used to log the personal profile and musculo-skeletal discomfort of the respondents. Neck and lower back (100\% each), ankles (91.67\%), wrists/hands and upper back (83.33\% each) and shoulder $(75.00 \%)$ were the majorly 
affected body parts. Lifting and carrying heavy loads were occupied with high LI values.

\section{References}

Ergonomic Design for People at Work: Vol. 2, by Eastman Kodak Company. Van Nostrand Reinhold, 1986, and Kodak's Ergonomic Design for People at Work 2nd edition by Somadeepti, et al., 2004.

Keller, J.J. and Associates Inc., (2015) Article: Understanding the NIOSH lifting equation, safety and health magazine (DoA: 06/12/2019 at 3.37 PM)

Kuorinka I, Jonsson B, Kilbom A, et al.,
Standardized Nordic questionnaires for the analysis of musculoskeletal symptoms, Appl Ergon, 1987, vol. 18 (pg. 233-237)

R128 - Maximum Weight Recommendation, 1967 (No. 128) NORMLEX Information System on International Labour Standards

Waters, T. R., Putz-Anderson, V., Garg, A. and Fine, L. J. 1993. Revised Niosh equation for the design and evaluation of manual lifting tasks. Ergonomics, 36: 749-776.

www.ccohs.ca/oshanswers/ergonomics/niosh/ calculatin (DoA: 28/11/2019 at 6.21 AM)

\section{How to cite this article:}

Ekta Melkani, Ekta Kapri and Manju Mehta. 2020. WRMSD Related to Manual Material Handling of Indian Railway Porters. Int.J.Curr.Microbiol.App.Sci. 9(04): 2488-2493.

doi: https://doi.org/10.20546/ijcmas.2020.904.297 